\title{
The Albanian Social Security System and the Institutions of Social Protection in Albania
}

\author{
Laureta MANO Phd Cand.
}

Health Care Insurance Fund lauretamano@yahoo.com

\author{
Mirela SELITA Phd \\ University "Marin Barleti” selitamirela@yahoo. com
}

\begin{abstract}
The social security system in Albania consists of social assistance and social services, health services and health care insurance and social insurance schemes. In the social objectives of the constitution are declared that the State within the constitutional competencies and the probable means as well as in the fulfillment of private initiatives and responsibilities, aims to higher possible standards of health, physical and mental; social care and services of elderly, orphan and invalids; medical rehabilitation, special education and integration in the community, of disabled persons. The Constitution foreseen that everyone has the right of social insurance when retired or in case of incapacity of work under a certain system established by a law. Everyone, when is unemployed for any reasons independent on individual will and when there is no living means, has the right of need under the conditions foreseen by law. Social insurance is a scheme protecting by benefits persons in respect of temporary incapacity due to sickness, maternity, old-age, disability and loss of breadwinner, employment accidents/occupational diseases, unemployment. Social Services are benefits in kind for disabled persons or vulnerable persons. Social Assistances are cash benefits given to families in need, that means families with lower incomes comparable with minimum standard of living or families without incomes. Health services consist of public health, primary health care, hospitalization services nurse 's service, dental and pharmaceutical net. The Institutions of Social Protection in Albania are Social Insurance Institute, National Social Services and Health Care Insurance Fund.
\end{abstract}

Keywords Social protection, social insurance, health care, health insurance, social assistance, social service.

\section{Introduction}

The Albanian social security consists of social assistance and services, social insurance, health services and health care insurance.

In the social objectives of the constitution are declared that the State within the constitutional competencies and the probable means as well as in the fulfillment of private initiatives and responsibilities, aims to higher possible standards of health, physical and mental; social care and services of elderly, orphan and invalids; medical rehabilitation, special education and integration in the community, of disabled persons.

Article 52 of the Constitution foreseen that everyone has the right of social insurance when retired or in case of incapacity of work under a certain system established by a law. Everyone, when is unemployed for any reasons independent on individual will and when there is no living means, has the right of need under the conditions foreseen by law. In article 54 it is declared the right of a special state protection of children, young people, pregnant women and young mother. Article 55 of the Constitution provides the right to health care as a fundamental right with socio-economic character. This article clearly states the State's duty to guarantee health care for its citizens and the right to health insurance for all in accordance with the law 1 . This article also restates that citizens should not be discriminated and should be treated equally. The Constitution provides that health insurance procedures are regulated by law.

${ }^{1}$ Article 55 of the Constitution, the second paragraph of which reads: "Everyone has the right to health insurance under the procedure established by law 
Social security in Albania is regulated by acts of the Parliament, which are supported by sub legal acts of the Government or of the Administrative Councils (tripartite bodies). ${ }^{1}$

According to the Social Insurance Law the compulsory social insurance is non-profit making scheme, protecting by benefits employed persons in respect of temporary incapacity due to sickness, maternity, old-age, disability and loss of breadwinner, employment accidents/occupational diseases, unemployment, and other economically active persons (employers and selfemployed people) in respect of maternity, old-age, disability, and loss of breadwinner.

In accordance with the health insurance scheme provided for by law, in return of the insures contributions, health care service packages are covered by the scheme of the compulsory insurance. Those packages include visits, examinations and treatments in primary health care centers and in hospitals, private or pubic ones, drugs from the drugs reimbursment list and medical products. All these aspects are regulated with bylaws, most of them by the decisions of the Council of Ministers.

In the law on Social Assistance and Services the following definitions are used: Economic Assistance is meant the support in cash or in kind, to individuals with a special status and to families in need. Disability Entitlement is meant the monthly payment paid to disabled persons in compliance with the stipulations of this law. Social Services is meant the whole variety of services provided to individuals and groups in need, who are unable to meet, with their own resources, their life needs with a view to the preserving, developing and rehabilitating of individual abilities to fulfill emergency or chronic needs.

Ministry of Social Welfare and Youth is responsible for designing and monitoring of social protection policy.

Social Insurance Institute is an autonomous public institution, responsible for administration of sickness, maternity, professional disease/accident at work, old age, invalidity and survivor's insurance branches. The supreme executive body is Administrative Council, a tripartite body with the representative of Government-trade unions-employer's organizations. The SII administration is based on central office, regional offices and local agencies.

State Employment Service is a public institution on dependence of Ministry of Social Welfare and Youth. Payment of unemployment benefit is one of tasks of National Employment Service. Its administration is based on district offices.

State Social Service is a public institution on dependence of Ministry of Social Welfare and Youth. The State Social Service is based on one central office, regional offices and residential institutions. Social assistance and social services units are also established in each municipality and commune. The social administrators working in social assistance units are in a double dependency, on one side, from local authorities, and on the other side, from the State Social Services.

Compulsary Health Care Insurance Fund is the administrative body charged with implementing the scheme.

Ministry of Health is responsible for approving health policy and strategies. From the financial point of view it covers the financing of investment in the entire public sector of health services including $\mathrm{HC}$ and Hospitals, it is responsible for development of scientific research institutions, service quality and accreditation institutions and national health inspectorate.

\section{The healh care insurance}

The legal framework regulating the right to health insurance in the Republic of Albania is relatively broad and complex. The most important among them is Law no. 10 383, dated 24. 02. 2011 "On Compulsory health care in the Republic of Albania". The law that observes the constitutional obligation to determine the procedure by which everyone will have the right to health insurance is Law no. 10 383, dated 24. 02. 2011 "On Compulsory health care in the Republic of Albania". The law provides that health insurance in the Republic of Albania is a mandatory provision. Such a formulation raises the issue: Are we dealing with a right to health insurance or with the obligation to be insured to health?

${ }^{1}$ Representatives of government, trade unions and employer`s organizations 
On the other hand, such a formulation goes toward confirmation of the principle of universality. The thesis that compulsory schemes aimed at covering the entire population in a given country, is defined in the second paragraph of Article 4 of the law concerning the coverage of the population, as well as in the listing of categories of persons subject to compulsory health insurance. According to the law, beneficiers are divided into two groups: economically active persons (employees, self-employed, unpaid family workers, other economically active persons) and economically inactive persons (persons benefiting from the Institute of Social Security, people receiving social assistance or disability payments, in accordance with relevant legislation, persons registered as unemployed jobseekers in the National Employment Service, foreigners seeking asylum in Albania, children under the age of 18, pupils and students under the age of 25 years, upon condition that they do not receive incomes from economic activities, categories of persons defined by special laws. ${ }^{1}$

Covered Groups. In theory, all population groups have been covered by health insurance. However, the law has provided for the opportunity to protect any isolated individual who is not included in the categories provided by law. Voluntary insurance will help in avoiding such cases ${ }^{2}$. This approach is a further development and protection of the constitutional right to health insurance. Some ideas that circumstances mentioned above do not present the features of an obligation, but the right of the individual to freely choose joining of the scheme are already expressed. However, we think that this choice is again indirectly binding, because the uninsured person who needs medical care, can get this service by paying its full cost. So, it goes without saying that those who do not comply with the procedure established by law shall not be treated equally from the financial standpoint. On the other hand, when someone joins the voluntary insurance scheme, he/she shall have the right to equally benefit the same amount just like the rest of the obligatory insured population ${ }^{3}$. As explained above, the universal principle of health insurance is applied not only for Albanian citizens but also for foreign nationals and stateless persons to whom the Constitutional provisions refer as "anyone".

Every person participating in the scheme is called insurant. Participation in the scheme is based on the payment of contributions. Contributions are paid from income of economically active persons and the state budget, which pays for economically inactive persons. We have to do in this way with the ideology of another important principle of health insurance schemes - the principle of solidarity.

Changes made to the law during the year 2014, were mostly intended at the expansion of social protection by including even the category of the trafficked victims into the compulsory insurance and that the Compulsory Health Insurance Fund finance health service packages provided by health service providers (hospitals) abroad. In this way, the government targets to enhance the health services quality delivered to the population shall be executed.

Financial Resources. Under this law, the Fund realizes coverage of health care services packages that are included in the scheme, through these resources:

- compulsory contributions to health insurance, which are obtained from the contributions of economically active persons according to the categories defined in Article 5, paragraph 1 of Law, which means employees, self employed, unpaid family workers etc.

- the contribution of compulsory health insurance from State Budget for economically inactive persons, according to paragraph 2 of Article 5 of the law, which means contributions for persons benefiting from the Institute of Social Security, people receiving social assistance or payment for persons with limited abilities, in accordance with relevant legislation, persons registered as unemployed jobseekers in the National Employment Service, foreigners seeking asylum in Albania, children under the age of 18 , etc.

- voluntary health insurance contributions, according to paragraph 3 of Article 5 of the law which are foreseen for that part of the population that, for specific reasons, are not included in the categories of compulsory insurance.

- transfers from the Ministry of Health to subsidize a portion of direct payments. These transfers come as the financial support of various social policies that the government can undertake to facilitate various social categories in need.

\footnotetext{
${ }^{1}$ Article 5 of the Law no. 10383 dated 24.02.2011 "On Compulsory health care in the Republic of Albania.

2 Article 5/3 of the Law no. 10383 dated 24.02.2011 "On Compulsory health care in the Republic of Albania

${ }^{3}$ Stefan Grezd, Regulated competition in social health insurance, International Social Security Review, Vol.59/2006
} 
- transfers from the Ministry of Health for the services required of it, beyond those budgeted or contracted by the Fund, targeting financial guarantee to cover the predefined service packages.

- transfers approved in the state budget to balance the budget of the Fund or for compensation of unrealized contributions due to implementation of the budget process, which does not allow de facto the bankruptcy of the Fund.

There are other financial resources that come from other alternative sources such as donations and grants from national and international sources. The law provides for rules on the Fund's financial resources, financial structure and rules of accounting and auditing. Meanwhile it underlines that the Fund manages its activities within the available financial resources, it is not included in debt, does not cover health care services outside the compulsory insurance package and observes the relevant contracts.

The contribution rate. The rate of contributions to health insurance is 3.4 percent of the basis for calculating contributions. In this way, the new law introduces the unification of contribution rate for all the insured. This represents a change compared to the previous law under which employees (including foreigners) paid a fixed contribution of $3.4 \%$ of gross salary. For the self-employed and unpaid family workers the contribution was $7 \%$ and self-employed and unpaid family workers working in the countryside, the contribution was $5 \%$ on the field areas and $3 \%$ on hilly and mountainous areas. For the category of self-employed workers and for voluntary insured people, the unified percentage will be not calculated based on the minimum wage, but on the average between minimal and maximal wage due to contributions calculation.

Collection of contributions. The procedure on the practical implementation of the process of realization of the constitutional right to health insurance is set out in the Law No. 9136, dated 11. 9. 2003 "The collection of mandatory social and health insurance contributios in the Republic of Albania". The law regulates the collection of compulsory contributions to health insurance and decisions issued pursuant thereto. The Fund is not directly responsible for the collection of contributions. The Ministry of Finance collects these contributions through the Directorate General of Taxation, which operates through local offices in the districts since they are responsible for the collection of contributions and taxes and their distribution to the respective institutions. According to this Law and other relevant bylaws, and taking into account that a part of the Fund budget is included in the state budget, arrears in the payment of taxes or penalties imposed on entities for not registering, or paying health insurance contribution in time do not pass in favor of Fund, somethingt that negatively affects the fund of this institution.

Benefits from mandatory schemes, services packages. One of the innovations that this law introduces is that the Fund shall exercise its functions through development and purchase of health services packages by health care provider. In this way, the Fund achieves an active function.

Another specific aspect is that the law creates flexibility in the process of drafting packages associated with the respective prices, taking into consideration the solvency of the Fund's budget. This implies that not all types of services can be included in the package financed by the Fund. On the other hand, the law sets out the medical, economic and social criteria on the basis of which packages of services will be drafted, such as to what extent the service impacts expectancy, effectiveness, the cost of service, the solvency of the population.

Drafting of services packages is made by technical committees, the experts of which equally represent medical, economic and social criteria. Members of the Technical Committees are appointed by the Fund's Administrative Council according to the rules set out in the Fund's Statute. The Administrative Council of the Fund approves the draft packages proposed by the technical committees and sends them to the Minister of Health for processing by the Council of Ministers. The proposed package is accompanied by a financial report of the Fund's General Director, on financial coverage options of the packages proposed by the Fund.

Council of Ministers basing on the social policy of the Government, may exclude from direct payments some specific categories of individuals, based on their ability to pay. In these cases, the Council of Ministers provides extra funds (subsidies) to fund health service providers cost of direct payments. Lately, Council of Ministers specified briefly those categories, which receive benefits from health insurance scheme on free of charge basis. The group of children from 0 to 18 years old, the disabled, veterans, orphans and those who enjoy the status of ex-convicts and persecuted are included at the categories which are specifically patronized. The act provides for exemption from co-payments of reimbursable drugs some categories such as pensioners, detainees and prisoners, asylum seekers and victims of trafficking, which were recently added to the scheme. 
One important development recently, is the decision to cover the basic Check-up by health insurance. The basic Check-up is a national program aimed at screening the population for risk factors and prevalent diseases as a prelude for the health care, prevention of diseases and complications, early detection of disorders, treatment in the early stages and improvement of the health culture. The Council of Ministers decision determines that all citizens aged 40-65 year with permanent residence in the Republic of Albania, benefit free of charge from the national program of the basic Check-up, which is funded by Compulsory Health Insurance Fund. The Ministry of Health is the body that designs protocols of each component of the Check-up package implementation and defines the criteria on the movement of citizens in the health system in order to benefit this check-up and approves the health institutions where the Check-up will be carried out. It ensures the full coverage of the group age specified in this decision according to the population coverage area, the distances of infrastructure and availability and distribution of the medical and supportive personnel. This act is an important step towards universal health coverage, which is one of the most important points in the government program on health.

\section{The Social Insurance}

The social insurance scheme in Albania aims to guarantee full coverage with the mandatory social insurance, held at acceptable levels, that responds better to the stage reached in the economic and social development of the country, better management of social insurance scheme, especially of contributions collection as well as adequate distribution of benefits, where and when the right conditions arise, to improve financial sustainability of social insurance scheme etc. ${ }^{1}$

This is a scheme financed out of contributions from the employers, the employed persons and self-employed. Coverage starts on the date the protected person has legally commenced the economic activity and finishes on the date economic activity ends. In order to be entitled to benefits each individual has to contribute to the specific branch. The insurance period includes all periods for which contributions are paid and during which a benefit was awarded by social insurance. The contributions are collected by tax force ${ }^{2}$. The majority of benefits are paid by the post offices and the others by banks.

Old age, survivor's, incapacity at work, unemployment fund is financed by the contributions of employer's employees and self employed persons as well as contributions from the state budget in respect of persons, who cannot pay contributions, especially the citizens serving compulsory military service etc. Payment of social insurance contributions enjoys a priority in comparison with fiscal liabilities and arrears. Social insurance benefits are tax-free. Social insurance fund is independent of the state budget, but the state guarantees the solvency of the fund.

Management of social insurance. Social insurance scheme is managed by the Social Insurance Institute (SII) $)^{3}$ which is an autonomous public institution. SII is responsible for administration of sickness, maternity, professional disease/accident at work, old age, invalidity and survivor's insurance branches. The supreme executive body is Administrative Council, a tripartite body with the representative of Government-trade unions-employer's organizations. The SII administration is based on central office, regional offices and local agencies.

Person covered by the social insurance scheme. Social insurance protects all the employees in case of earnings reduction due to temporary incapacity caused by sickness, maternity, employment accidents/professional diseases, unemployment and due to old age and survivorship. Social Insurance provides compulsory protection to all economically active persons in case of income reduction due to maternity, old-age, disability and loss of breadwinner. The Council of Ministers may decide on other area of protection and on exceptions for self-employed people in agriculture, unpaid family workers of self-employed people, for seasonal and temporary workers, apprentices and students during the period of practice; these persons are insured by employers for employment accidents only ${ }^{4}$. Social Insurance also provides protection to foreign citizens working in Albania. Foreigners employed and insured in Albania are covered by the compulsory health insurance scheme.

\footnotetext{
1 Long-Term Strategy of Social Insurance 2000-2020

2 Law no. 9136, date 01.09 .2003 "On the collection of the compulsory social and health insurance contributions", as amended.

${ }^{3}$ Article 71 of the Law no.7703, date 11.5.1993 \& Council of Ministers Decision no.249, date 5.6.1992

${ }^{4}$ By the decisions of Council of Ministers
} 
Contributions. The employer is obliged to pay contributions for the employee to the sickness, maternity unemployment, labour accident, pensions. Contributions shall be shared by employee and employer and shall be calculated based on monthly wage, having as minimal and maximal wage that defined by the Council of Ministers upon which social insurance contributions are paid. For sickness, maternity and pensions contributions are divided between employer and employee. For employment accidents/occupational diseases and unemployment insurance branches only employer is obliged to pay contributions. The self-employed or employer are obliged to pay contributions for maternity and pension. They are responsible to pay by themselves the contributions to the tax office.

Employer will pay fines if the contributions are not paid within the time terms. Penalties will be paid for not registering the economic activity, for delayed registration of a new economic activity, for delayed submission of the documents required, as well as in case the documents submitted by the employer comprise defaulted contribution-related figures aiming reduction of contribution amount. Penalties are to be paid in case an employer has deducted social insurance contributions from employed person's wage, but has not paid it and if the employer does not keep the records in conformity with the procedures determined. Each person obliged to pay contributions have the right to appeal the estimation of additional contribution of interests and penalties. The employer and the self employer may appeal in written to the tax authorities.

Old-age pensions branch. The legal retirement age is 65 years old for men and for women was 60 years. But since 1 January $2015^{1}$ the age will be increased by two month per year up to 65 . The monthly old-age pension is composed of a social pension and an increment.

Survivor's pensions branch. Survivor's pension is a benefit given to those persons who are dependent upon the deceased person who was or would have been entitled to an old-age or disability pension'2. Surviving spouse is an entitled person if she is caring for a dependent child of deceased person, up to 8 years old; or she is disabled; or she is 55 years old and widower if he is caring for a dependent child of deceased, up to 8 years old or he is disabled or he is 60 years old. The widow and widower shall lose their right to a survivor's pension on marriage. Orphans shall be eligible to a survivor's pension, provided they were dependent upon the deceased and are under 18 years of age, or 25 years, if studying or disabled, prior to the above mentioned ages. Orphans having lost one parent shall be entitled to a portion of the pension the deceased person had or would have had. It shall be $25 \%$ for each of them. If there are no other survivors, the survivor's pension shall be $50 \%$. Orphans having lost both parents shall receive an orphan's pension in respect of each of them.

Sickness cash benefits. When an insured person is medically certified as being temporarily incapable to work because of general diseases, he /she are entitled to a sickness cash benefit ${ }^{3}$. They do get the benefit if the temporarily incapable occurred within 30 days of compulsory insurance termination. The benefit is not provided if the employed person was dismissed for criminal act, according to a Court Decision. The benefit period start on the 15th day of medical certification of such incapacity and shall last for not more than 6 months from the beginning of the payment. It may be exceptionally prolonged up to another 3 months, provided a Medical Experts Committee certifies that the insured person concerned shall recover in that period and be not eligible to a disability pension. When an insured person is entitled to a partial disability pension, the cash temporary incapacity of work benefit shall be provided of 3 months from the starting of payment partial disability pension. The duration of payment of cash sickness benefit for seasonal and temporary workers who have been employed at least 3 months in the last 12 months, shall be up to 75 days. Benefits in case of sickness, for periods up to the first 14 days, or nursing a dependent child, is a liability of the employer, foreseen in the Labor Code. Sickness allowance awarded to compensate job place changing or reduction of working hours, is another cash benefit. In that case a decision of Medical Expert Committee is to be taken. The period of compensation can't be more than 3 months within one year from the date the disease, due to which the employment was changed, began.

Maternity and paternity ${ }^{4}$ cash benefits. In case of maternity the following cash benefits are awarded: the maternity benefits, the maternity allowance, due to employment change and birth grant. ${ }^{5}$

\footnotetext{
1 The new pension's reform in Albania and the law no.104/2014 "On some amendaments on the Social Insurance Law no.7703, date 11.05.1993", Official Gazette no.137/2014

2 Articles 40-42 of the Social Insurance Law no.7703, date 11.3.1993, as amended

${ }^{3}$ Articles $20-25$ of the Social Insurance Law no.7703, date 11.3.1993, as amended

4 The new social insurance law foreseen the paternity leave, so far the child care is a benefit provided to mother or father of the child

${ }^{5}$ Articles 26-29 of the Social Insurance Law no.7703, date 11.3.1993, as amended
} 
The maternity benefit is paid to the insured woman with regard to pregnancy and childbirth provided she has acquired 12 months of insurance. Period of benefit is 365 calendar days, including a minimum of 35 days prior to and 63 days after childbirth. If during the pregnancy are more than one child, the benefit period is 390 calendar days, including a minimum of 60 days prior to and 63 days after child birth. When a child of up to one year of age is adopted, the adoptive mother, having not less than 12 months of insurance, will benefit from the day the adoption occurred, but not prior the 63nd day of childbirth, subject to a maximum of 330 days from baby delivery. The maternity allowance benefit is to reimburse loss of wage because of employment change for reasons of pregnancy, in conformity with a decision of Medical Experts Committee, if the contributions are paid at least 1 year, prior to being eligible to benefit.

Unemployment insurance branch. ${ }^{1}$ The insured person shall be entitled to an employment benefit, provided he has contributed to social insurance for at least 12 months for each benefit contingency; it is certified by the responsible labor office that: they are unemployed job-seekers, available to get employed, provided they are offered a paid and appropriate job; accept to be qualified or re-qualified. The unemployment benefit shall be flat rate. The persons, who are attending training and retraining courses, are entitled to unemployment benefit, if they are not paid for this period. The payment of benefit should not exceed 6 months beyond 1 year of unemployment benefit. This right is also enjoyed by insured persons under maternity benefit and full disability pension. Employment office of the district is responsible to administer the requests for unemployment benefits.

Invalidity pensions branch. Invalidity pension is delivered because of a general illness. The competent Medical Expert Committee decision that determines the ability to work as well as, for physical or mental disabled persons, the need for a permanent care of someone else. On reaching pension able age the disability pensioner shall have the right to opt for an oldage pension, if that shall be more favorable for him.

A disability pension shall be suspended for periods the pensioner refuses to visit the competent medical expert committee. It shall also be suspended when he refuses to participate in training/retraining courses or undergo medical rehabilitation or treatment against alcohol and drugs, which aim to retrieve his capacity for work.

Employment injuries/occupational diseases. ${ }^{2}$ If a person suffers an employment accident/occupational disease, regardless the work stage can be entitled to benefit additional medical care and rehabilitation necessary to recover lost abilities; benefit in case of incapacity, compensation for reasonable damages \& benefit in case of death. If the capacity to work is loosed, the benefits provided are: Benefit in respect of temporary incapacity, if the employment accident/occupational disease, is certified by a competent medical expert committee.

\section{Bibliography}

[1]

[2] Alesina, A. , Glaeser, E "Fighting Poverty in the US and Europe: A World of Difference. ", Oxford University Press, Oxford, 2004

[3] Beaudry, R. "Workfare and Welfare: Britain's New Deal" York University, Great Britain, 2002

[4] Berghman, Jos, "Basic concepts on social security in Europe", edition of International Social Security Review, volumi 32, nr. 4/1995

[5] Consultancy "Assisting in defining a social security frame-work to Albania compatible with the European code of social security".

[6] Council of Europe, November 2000

[7] European Code of Social Security, European Treaty Series/48

[8] European Convention on Social and Medical Assistance, Euopean Treaty Series/79

\footnotetext{
${ }^{1}$ Articles 53-55 of the Social Insurance Law no.7703, date 11.3.1993, as amended

2 Articles 35-39 of the Social Insurance Law no.7703, date 11.3.1993, as amended 
[9] European Convention on Social Security, European Treaty Series/78

[10] European Interim Agreement on Social Security Schemes other than Old Age, Invalidity and Survivors, European Treaty Series/13

[11] European Interim Agreement on Social Security Schemes realting to Old Age, Invalidity and Survivors, European Treaty Series $/ 12$

[12] European Social Charter, European Treaty Series, No. 163, 1998

[13] Good practices in Social Services Delivery in South Eastern Europe, 2004 ILO, Elaine Fultz, Martin Tracy, 399 pages.

[14] Law no. 8960, date 24. 10. 2002 "On the ratification of the Revised European Social Charter"

[15] Law no. 9442, date 16. 11. 2005 "On the ratification of the ILO Convention "Minium standart of social security"no. 102"

[16] Merita (Vaso) Xhumari, Social Policy Process and Institutions, Tirane 2003. 290 pages, ISBN 99927-0-241-9

[17] Neubourg, C, Nelissen, E, Hener E. "Trends in Welfare Reform", University Maastricht, Maastricht, 2004

[18] Prof. Ilia Telo Welfare and Minimum Standard of Living, Tirane 1998. 202 pages 